\title{
ANALISIS AKTIVITAS ANTIOKSIDAN, ANALISIS KANDUNGAN GIZI, UJI ORGANOLEPTIK SNACK BAR SESAME SEED DAN TEPUNG LABU KUNING SEBAGAI ALTERNATIF MAKANAN SELINGAN DENGAN TINGGI ANTIOKSIDAN
}

\author{
Afiyah Ratna Hastuti, Diana Nur Afifah* \\ Departemen Ilmu Gizi, Fakultas Kedokteran, Universitas Diponegoro \\ Jl. Prof. Sudarto SH, Tembalang, Semarang, Jawa Tengah 50275, Indonesia \\ *Penulis Penanggungjawab. E-mail: d.nurafifah.dna@fk.undip.ac.id
}

\begin{abstract}
Background : Dislipidemia are increasing trend in developing countries. Hyperlipidemia causes in increasing ROS production, affecting antioxidant enzyme, and plays an important role in inflamation response. Sesame seed and pumpkin snack bar can be alternative snack with high antioxidant. This study aimed to analyze proximate, antioxidant activity, phenolic content, and acceptibility of sesame seed and pumpkin flour snack bar.

Metode :The completely randomized single-factor experimental design which was 3 types of sesame seed percentage (95\%, 90\%, dan $85 \%)$ and pumpkin flour percentage (5\%, 10\%,dan 15\%). The nutrient content (energy, carbohydrate, fat, protein, and water) analyze with one way anova and man whitney. The acceptibility of sesame seed and pumpkin snack bar analyzed with kruskal wallis.

Results : There were no difference between energy and macronutient content with formulation of sesame seed and pumpkin flour snack bar ( $p>0.05)$. There were difference between fiber, water, ash, antioxidant activity, total fenol with snack bar formulation. There was no difference the acceptability with color, flavor, texture of snack bar.

Conclusion : Snack bar with $85 \%$ of sesame seeds and $15 \%$ of pumpkin flour has a good acceptibility
\end{abstract}

Kata kunci : sesame seed; snack bar; antioxIdant; phenol; proximate

\begin{abstract}
ABSTRAK
Latar Belakang : Penyakit tidak menural termasuk dislipidemia menjadi masalah yang terus mengalami peningkatan. Hiperlipidemia termasuk dislipidemia mengakibatkan peningkatan produksi reaksi oksigen reaktif (ROS) dan mampu mempengaruhi enzim antioksidan pada reaksi anti-oksidatif serta berperan penting pada respon inflamasi. Snak bar sesame seed dan labu kuning mempunyai kandungan makro dan mikro nutrien yang patut dipertimbangkan. Tujuan penelitian ini adalah untuk menganalisis proksimat, aktivitas antioksidan, total fenol, dan tingkat penerimaan snack bar sesame seed dan tepung labu kuning.

Metode : Penelitian ini merupakan jenis eksperimental rancangan acak lengkap satu faktorial dengan 3 variasi persentase sesame seed (95\%, 90\%, dan 85\%) dan tepung labu kuning (5\%, 10\%,dan 15\%). Analisis statistik kandungan energi, karbohidrat, lemak, protein, serat, dan air menggunakan one way anova 95\% dengan uji lanjut tukey dan kandungan total fenol, abu, dan aktivitas antioksidan menggunakan uji kruskal wallis dengan uji lanjut mann whitney, sedangkan tingkat penerimaan menggunakan kruskal wallis

Hasil : Kandungan energi dan makronutrien (karbohidrat, protein, lemak) tidak terdapat perbedaan terhadap formulasi snack bar sesame seed dan tepung labu kuning ( $p>0,05)$. Terdapat perbedaan kandungan serat, air, abu, aktivitas antioksidan, dan total fenol terhadap formulasi snack bar

( $p<0,05)$. Tingkat penerimaan dengan parameter warna, aroma, tekstur, dan rasa tidak terdapat perbedaan ( $p>0,05)$.
\end{abstract}

Simpulan: Formulasi snack bar terpilih adalah dengan persentasi $85 \%$ sesame seed dan 15\% tepung labu kuning.

Kata kunci : sesame seed; snack bar; antioksidan; total fenol; analisa proksimat

\section{PENDAHULUAN}

Penyakit tidak menular menjadi pembunuh nomor satu di dunia, yang mengakibatkan 60\% kematian secara global dan 35 juta orang meninggal setiap tahunnya. Hal ini menjadi ancaman terbesar dalam proses penanganan dan perawatan kesehatan. ${ }^{1}$ Dislipidemia menjadi salah satu faktor penting dalam perkembangan penyakit kardiovaskular. Dislipidemia menyebabkan sepertiga dari penyakit jantung iskemik dan seperlima dari penyakit serebrovaskular atau setara dengan terjadinya 2,6 juta kematian setiap tahun di seluruh dunia. ${ }^{2}$

Dislipidemia merupakan suatu kondisi kelainan lipid yang ditandai dengan peningkatan serum kolestrol total, peningkatan low-density lipoprotein (LDL), penurunan konsnetrasi highdensity lipoprotein (HDL), peningkatan trigliserida, dan kombinasi berbagai prediktor tersebut. ${ }^{3}$ Terjadi peningkatan kolestrol secara global pada tahun 2008 sebanyak $39 \%$ yaitu $37 \%$ untuk pria dan $40 \%$ untuk 
wanita. Peningkatan kolestrol tertinggi terjadi di WHO European Region sebanyak 54\%, diikuti WHO Region of the Americas sebanyak 48\%, dan terendah pada WHO African Region dan WHO South-East Asian Region masing-masing sebanyak $23 \%$ dan $30 \% .^{4}$

Hiperlipidemia termasuk dari dislipidemia mengakibatkan terjadinya peningkatan produksi spesies oksigen reaktif (ROS) dan mampu mempengaruhi enzim antioksidan pada reaksi antioksidatif. ${ }^{5}$ Peningkatan generasi intraseluler spesies oksigen reaktif (ROS) memainkan peran penting dalam respon inflamasi kronik. ROS bereaksi dengan biomolekul seperti lipid, karbohidrat, protein, asam nukleat, dan makromolekul jaringan ikat yang kemudian akan mengganggu fungsi sel. Produksi ROS yang berlebihan akan menyebabkan terjadinya kerusakan sel dan mengganggu hemostasis sel dengan menghancurkan makromolekul seperti asam nukleat, lipid, karbohidrat, dan protein. ${ }^{6}$ Gangguan keseimbangan produk antioksidan dan oksidan akan memprovokasi terjadinya stress oksidatif. Stress oksidatif sendiri akan menyebabkan terjadinya berbagai spektrum penyakit yang lebih luas. Hiperlipidemi banyak menghasilkan terjadinya stress oksidatif. ${ }^{7}$

Tanaman dengan berbasis senyawa seperti polifenol, flavonoid dan tannin mampu memberikan efek antioksidan dan efek perlindungan terhadap kerusakan yang diakibatkan oleh radikal bebas. ${ }^{8}$ Senyawa antioksidan menjadi salah satu senyawa yang mampu menstabilkan ROS. Senyawa antioksidan akan menyumbangkan elektron mereka untuk menstabilkan radikal bebas dan membuat senyawa menjadi lebih stabil sehingga mampu meminimalisir efek berbahaya dari radikal bebas. ${ }^{9}$

Sesame seed merupakan salah satu bahan makanan yang sudah dikenal sejak lama dan secara luas dibudidayakan di daerah tropis termasuk Asia dan Afrika. ${ }^{10}$ Sesame seed (Sesamun indicum L.) mempunyai kandungan gizi cukup baik dikarenakan jumlah yang cukup signifikan dari serat pangan, protein, asam lemak tak jenuh, vitamin, mineral, dan antioksidan. Fraksi lipid pada sesame seed juga menunjukkan stabilitas oksidatif yang baik, yang dikaitkan dengan asam lemak essensial seperti oleat, linoleat, dan arakidonat. Selain itu juga dapat ditemukan komponen senyawa antioksidan (tokoferol, sesaminol, sesamolinol, dan pinoresinol) dan lignan (sesamin dan sesamolin). ${ }^{11,12}$

Aktivitas antioksidan sesame seed telah dikaitkan dengan efek sinergis vitamin $\mathrm{E}$ dengan lignan yang berfungsi untuk detokfikasi radikal hidroksil yang kemudian menginduksi penurunan peroksidasi lipid. Selain itu kandungan polifenol terutama lignan pada sesame seed juga mengatur metabolisme tokoferol dan meningkatkan akumulasi tokoferol di plasma dan jaringan. ${ }^{16 / 12}$ Lignan terutama pada sesame seed merupakan salah satu jenis polyphenol yang mempunyai peran sebagai phytoestrogen. Lignan merupakan senyawa bioaktif yang juga biasa disebut phytohormones dilaporkan mempunyai aktivitas hampir sama dengan hormon. ${ }^{13}$

Pada penelitian sebelumnya lignan pada sesame seed mampu meningkatkan aktivitas dan ekspresi gen dari fatty acid oxidation enzyme di hati tikus. ${ }^{14}$ Studi lain juga menyebutkan bahwa suplementasi sesame secara signifikan mampu meningkatkan kapasitas antioksidan pada pasien hiperkolesterolemik. Selain itu, efek suplementasi harian sesame seed menghasilkan penurunan total kolestrol sebanyak $6,4 \%$ dan penurunan LDL sebanyak $9,5 \%{ }^{15}$ Penelitian yang dilakukan pada atlet dengan intervensi menggunakan sesame seed sebanyak 40 gram selama 20 hari menunjukkan penurunan kadar MDA yang signifikan $(\sim 55 \%)$, selain itu mengalami peningkatan SOD yang cukup signifikan. ${ }^{11}$ Penelitian lain juga menunjukkan, intervensi 40 gram sesame seed selama 60 hari pada pasien hiperlipidemia secara signifikan terjadi penurunan pada total serum kolesterol, LDL-C, dan rasio TC/HDL-C. Selain itu terjadi penurunan pada lipid peroksidasi (TBARS) dan peningkatan pada aktivitas GPX dan SOD. ${ }^{16}$

Bahan makanan lain seperti labu kuning kaya dengan kandungan vitamin, mineral, karoten, dan juga serat. Kandungan $\beta$-karoten sebesar 142,38 $\mathrm{mg} / 100 \mathrm{gram}$ yang terdapat pada labu dikonversi menjadi vitamin A dalam tubuh dan mempunyai peran penting dalam pencegahan penyakit kronik dikarenakan kemampuannya sebagai antioksidan. Tepung labu kuning merupakan salah satu olahan yang mempunyai keunggulan dalam kandungan serat pangan yang tinggi. Sehingga bisa dimanfaatkan untuk subtitusi produk makanan yang mempunyai rendah serat. ${ }^{17}$

Sebelumnya pemanfaatan jenis bahan makanan tersebut masih belum maksimal dan beberapa hanya sebagai bahan tambahan makan untuk jenis makanan tertentu. Berdasarkan beberapa latar belakang yang sudah dijelaskan, diharapkan snack bar sesame seed dan tepung labu kuning menjadi salah satu produk pangan alternatif untuk penderita dislipidemia maupun penyakit degeneratif lainnya. Selain itu, diharapkan snack bar ini mengandung mutu gizi yang baik dan sesuai dengan kebutuhan.

\section{METODE}

Penelitian ini termasuk dalam bidang keilmuan food production yang dilakukan pada bulan Maret-April 2019. Pembuatan produk, analisis 
antioksidan, pengujian total fenol, dan analisis proksimat dilakukan di Laboratorium Terpadu Universitas Diponegoro Semarang. Sedangkan untuk pengujian pada tingkat penerimaan produk terhadap panelis agak terlatih dilaksanakan di Kampus Program Studi Ilmu Gizi Universitas Diponegoro.

Penelitian ini sendiri merupakan jenis penelitian dengan rancangan acak lengkap satu faktorial, dengan variasi tiga formula pada kadar sesame seed dan tepung labu kuning. Setiap pembuatan produk formulasi dilakukan pengulangan sebanyak tiga kali serta dilakukan pengambilan data secara duplo yaitu sebanyak dua kali. Berikut dibawah ini merupakan formulasi perbandingan sesame seed dan tepung labu kuning.

Tabel 1. Formulasi Snack Bar

\begin{tabular}{lcc}
\hline Formulasi & $\begin{array}{c}\text { Sesame Seed } \\
(\boldsymbol{\%})\end{array}$ & $\begin{array}{c}\text { Tepung Labu } \\
\text { Kuning (\%) }\end{array}$ \\
\hline SSSB1 & $95 \%$ & $5 \%$ \\
SSSB2 & $90 \%$ & $10 \%$ \\
SSSB3 & $85 \%$ & $15 \%$ \\
\hline
\end{tabular}

Bahan baku utama sesame seed didapatkan dari Bandung, Jawa Barat sedangkan bahan baku tepung labu kuning didapatkan dari Yogyakarta. Sedangkan untuk bahan tambahan lain seperti sirup agave didapatkan dari Jakarta. Bahan tambahan lain seperti margarin, vanilla essence, cinnamon powder, dan stevia didapatkan di toko bahan kue di Kota Semarang.

Pembuatan snack bar dimulai dengan membuat dua macam adonan, yaitu adonan basah dan adonan kering. Adonan kering terdiri dari campuran sesame seed, garam, dan tepung labu kuning, serta beberapa bahan tambahan pangan. Sedangkan untuk pembuatan bahan basah terdiri dari campuran margarin cair, sirup agave, vanilla essence, cinnamon powder, dan stevia. Setelah bahan basah tercampur secara merata, kemudian ditambahkan pada pada bahan kering dan dicampur secara merata. Adonan yang tercampur rata ditempatkan pada pyrex yang telah dilapisi kertas roti. Adonan yang telah siap dioven selama 25 menit dengan suhu $150^{\circ} \mathrm{C}$, setelah adonan siap kemudian didinginkan selama 1-2 jam.

Snack bar sesame seed dan tepung labu kuning yang terdiri dari tiga formulasi berbeda dlikukan uji kadar total fenol menggunakan metode Follin Ciocalteu dan uji aktivitas antioksidan menggunakan metode 2,2-difenil-1-pikrilhidrazil (DPPH). Selain itu pada sampel dengan formulasi yang berbeda tersebut dilakukan analisis proksimat untuk mengetahui kadar lemak, protein, serat kasar, abu, dan air. Produk snack bar juga diuji tingkat penerimaan yang menggunakan panelis agak terlatih sebanyak 25 orang mahasiswa Program Studi Ilmu Gizi Universitas Diponegoro. Uji tingkat penerimaan meliputi warna, aroma, tekstur, dan rasa. Skoring uji tingkat penerimaan dikategorikan menjadi skala 1 sampai 4 , yaitu $1=$ sangat tidak suka, $2=$ tidak suka, $3=$ suka, dan $4=$ sangat suka.

Analisis proksimat yang dilakukan pada produk meliputi kadar abu dan air menggunakan metode gravimetri, kandungan protein menggunakan metode kjedahl, kandungan lemak menggunakan soxhlet, dan kandungan serat menggunakan metode AOAC. Kandungan karbohidrat diperoleh dengan menggunakan metode by difference. Sedangkan untuk kandungan energi didapatkan dengan perhitungan $9 \mathrm{kkal} / \mathrm{g}$ lemak $+4 \mathrm{kkal} / \mathrm{g}$ protein +4 $\mathrm{kkal} / \mathrm{g}$ karbohidrat. Analisis data menggunakan software statistika SPSS 23. Data orgnanoleptik uji penerimaan produk dianalisis menggunakan uji beda Kruskal Wallis. Sedangkan data nilai kandungan aktivitas antioksidan, total fenol, dan kadar abu yang terdistribusi normal dianalisis menggunakan uji One Way Anova. Data yang tidak berdistribusi normal seperti kandungan energi, karbohidrat, protein, lemak, serat, dan air dianalisis menggunakan uji Kruskal Wallis.

\section{HASIL \\ Hasil Analisa Kandungan Gizi Produk}

Tabel 2 merupakan hasil analisa kandungan gizi produk snack bar sesame seed dan tepung labu kuning yang menggunakan analisa proksimat meliputi energi, karbohidrat, lemak, protein, serat, air, abu, dan aktivitas antioksidan, dan total fenol.

Hasil analisa proksimat yang dilanjutkan dengan uji SPSS menunjukkan bahwa kandungan energi tertinggi terdapat pada formulasi SSSB 3 sebesar 441,35. Sedangkan nilai terendah terdapat pada formulasi SSSB 1 sebesar 416,619. Nilai kandungan karbohidrat tertinggi terdapat pada formulasi SSSB 1 yaitu sebesar 62,56, sedangakan nilai terendah terdapat pada formulasi SSSB 2 yaitu sebesar 58,44. Berdasarkan tabel, nilai kandungan lemak produk yang tertinggi terdapat pada formulasi SSSB 3 yaitu 14,45 dan nilai terendah terdapat pada formulasi SSSB 1 yaitu sebesar 10,083. Kandungan makronutrien lain yang diperhatikan yaitu protein, berdasarkan hasil analisa didapatkan bahwa kandungan tertinggi terdapat pada produk formulasi SSSB 1 yaitu 18,94, sedangkan terendah terdapat pada formulasi SSSB 2 yaitu 16,95.

Hasil analisa kandungan serat menunjukkan bahwa kandungan tertinggi terdapat pada formulasi SSSB 1 yaitu 7,39 sedangkan kandungan terendah terdapat pada formulasi SSSB 3 yaitu sebesar 5,889. Kandungan air produk snack bar tertinggi terdapat pada formulasi SSSB 2 yaitu sebesar 7,41 sedangkan 
kandungan air terendah terdapat produk formulasi SSSB 1 yaitu 5,99. Analisa kandungan abu terbesar didapatkan pada formulasi SSSB 2 sebesar 2,823 dan nilai abu terendah terdapat pada formulasi SSSB 1 yaitu 2,411 .

Analisis statistika kandungan kadar abu menggunakan uji One Way ANOVA dikarenakan data normal yang didapatkan nilai $(p=0,000)$. Sehingga dapat diartikan bahwa terdapat perbedaan yang signifikan formulasi sesame seed dan tepung labu kuning terhadap kadar abu. Sedangkan kandungan energi, karbohidrat, lemak, protein, serat, dan air dianalisa menggunakan uji statistik Kruskal Wallis dikarenakan data tidak normal yang didapatkan nilai masing-masing sebesar $(p=0,325)$, $(p=0,977), \quad(p=519), \quad(p=0,221), \quad(p=0,011), \quad$ dan $(p=0,09)$. Dapat disimpulkan bahwa tidak terdapat perbedaan yang signifikan formulasi snack bar sesame seed dan tepung labu kuning terhadap kandungan energy, karbohidrat, lemak, dan protein. Akan tetapi terdapat perbedaan yang signifkan antara formulasi snack bar sesame seed dan tepung labu kuning terhdap kandungan serat dan air.

Tabel 2. Hasil Analisa Kandungan Gizi, Aktivitas Antioksidan, dan Total Fenol

\begin{tabular}{lllll}
\hline \multicolumn{1}{c}{ Zat gizi } & \multicolumn{3}{c}{ Formulasi } & p-value \\
\cline { 2 - 4 } & SSSB 1 & SSSB 2 & SSSB 3 & 0,325 \\
\hline Energi (kkal) & $416,619 \pm 12,09$ & $430,90 \pm 59,25$ & $441,35 \pm 23,71$ & 0,977 \\
Karbohidrat (gram) & $62,56 \pm 4,57$ & $58,44 \pm 14,301$ & $60,32 \pm 6,12$ & 0,519 \\
Lemak (gram) & $10,083 \pm 2,55$ & $14,36 \pm 12,15$ & $14,45 \pm 4,55$ & 0,221 \\
Protein (gram) & $18,94 \pm 2,06$ & $16,95 \pm 2,09$ & $17,616 \pm 2,16$ & 0,011 \\
Serat (gram) & $7,39 \pm 0,339^{\mathrm{a}}$ & $7,15 \pm 0,929^{\mathrm{a}}$ & $5,889 \pm 0,134^{\mathrm{b}}$ & 0,009 \\
Air (gram) & $5,99 \pm 1,124^{\mathrm{a}}$ & $7,41 \pm 1,37^{\mathrm{a}}$ & $4,99 \pm 0,464^{\mathrm{b}}$ & 0,000 \\
Abu (gram) & $2,411 \pm 0,1108^{\mathrm{a}}$ & $2,823 \pm 0,145^{\mathrm{b}}$ & $2,626 \pm 0,027^{\mathrm{c}}$ & 0,025 \\
Aktivitas Antioksidan (\%) & $92,207 \pm 1,069^{\mathrm{a}}$ & $93,263 \pm 0,585^{\mathrm{a}, \mathrm{b}}$ & $93,43 \pm 0,434^{\mathrm{b}}$ & 0,025 \\
Total Fenol (mg GAE) & $274,24 \pm 70,42^{\mathrm{a}}$ & $446,59 \pm 106,26^{\mathrm{b}}$ & $460,226 \pm 84,00^{\mathrm{b}}$ & 0 \\
\hline Ken
\end{tabular}

Keterangan : Huruf superscript berbeda (a,b,c,d) dibelakang angka menunjukkan beda nyata dengan uji Tukey $\alpha=0,05$.

Berdasarkan uji antioksidan yang telah dilakukan dengan menggunakan metode DPPH dan dilanjutkan dengan analisis menggunakan SPSS uji One Way ANOVA, didapatkan hasil bahwa terdapat pengaruh yang signifikan $(p=0,025)$ dari perbedaan persentase sesame seed dan tepung labu kuning terhadap aktivitas antioksidan. Hasil uji aktivitas antioksidan menunjukkan bahwa nilai tertinggi terdapat pada snack bar dengan formulasi SSSB 3 sebesar 93,43. Sedangakan aktivitas antioksidan terendah terdapat pada snack bar dengan SSSB 1 dengan nilai 92,207\%.

Kandungan total fenol pada snack bar yang telah diukur menggunakan metode Follin Ciocalteu dilakukan analisis menggunakan uji One Way Anova. Berdasarkan tabel 3 menunjukkan bahwa kadar total fenol tertinggi terdapat pada snack bar dengan formula SSSB 3 sebesar 460,226. Sedangkan kadar total fenol terendah terdapat pada snack bar dengan SSSB 1 sebesar 274,24. Berdasar uji statistik yang telah dilakukan didapatkan hasil bahwa terdapat pengaruh bermakna $(p=0,004)$ dari perbedaan persentase sesame seed dan tepung labu kuning pada snack bar.

\section{Uji Organoleptik Snack Bar Sesame Seed dan Tepung Labu Kuning}

Uji organoleptik dilakukan oleh panelis agak terlatih sebanyak 25 mahasiswa Program Studi Gizi Universitas Diponegoro. Hasil analisa uji normalitas menunjukkan bahwa data tingkat penerimaan snack bar sesame seed dan tepung labu kuning berdistribusi tidak normal, sehingga dilakukan analisis menggunakan uji Kruskal Wallis dengan derajat kepercayaan sebesar 95\%. Berdasarkan hasil uji pada tabel 3 tersebut menunjukkan bahwa tidak terdapat perbedaan yang signifikan pada warna $(p=0,108)$, aroma $(p=0,426)$, tekstur $(p=0,079)$, dan rasa $(p=0,354)$.

Berdasarkan uji organoleptik yang telah dilaksanakan dapat diketahui bahwa warna produk snack bar sesame seed dan tepung labu kuning yang paling banyak disukai terdapat pada produk dengan formula SSSB 3 dengan nilai rata-rata 3,25. Sedangkan produk snack bar yang paling sedikit disukai terdapat pada snack bar dengan formulasi SSSB 2 dengan rata-rata paling rendah yaitu sebesar 2,88 . Penilaian mengenai aroma produk yang mempunyai nilai rata-rata sama yaitu terdapat pada formulasi SSB1 sebesar 2,96 dan formulasi SSSB 2 sebesar 2,96. Sedangkan nilai rata-rata aroma yang terendah terdapat pada formulasi SSSB 3.

Berdasarkan parameter tekstur nilai rerata terbaik terdapat pada formulasi SSSB 3 dengan nilai 3,04. Sedangkan nilai rerata tekstur terendah terdapat pada formulasi SSSB 1 dengan nilai sebesar 2,54 . Dilihat dari parameter rasa, nilai rerata terbaik dan paling banyak disukai terdapat pada formulasi SSSB 1 dengan nilai 3,02. Snack bar dengan formulasi SSSB 2 mempunyai nilai rerata yang paling rendah yaitu 2,92 . 
Tabel 3. Hasil Kandungan Gizi

\begin{tabular}{lllll}
\hline Kategori & SSSB 1 & SSSB 2 & SSB 3 & p-value \\
\hline Warna & $3,20 \pm 0,764$ & $2,88 \pm 0,588$ & $3,25 \pm 0,676$ & 0,108 \\
Aroma & $2,96 \pm 0,611$ & $2,96 \pm 0,662$ & $2,71 \pm 0,908$ & 0,426 \\
Tekstur & $2,72 \pm 0,678$ & $2,54 \pm 0,859$ & $3,04 \pm 0,859$ & 0,079 \\
Rasa & $3,20 \pm 0,707$ & $2,92 \pm 0,628$ & $3,00 \pm 0,834$ & 0,354 \\
\hline
\end{tabular}

Hasil Formulasi Terbaik dan Kandungan Gizi Per Sajian

Formulasi terbaik dipilih berdasarkan beberapa pertimbangan meliputi ranking produk pada tiap pengujian. Berdasarkan uji organoleptik setelah dilakukan perangkingan secara berurutan formula produk terbaik adalah formula SSSB 1, formula SSSB 3, dan formula SSSB 2. Sedangkan berdasarkan kandungan gizi menggunakan analisa proksimat didapatkan bahwa formula SSSB 1 dan formula SSSB 3 mempunyai nilai yang sama. Pertimbangan yang terakhir adalah kandungan total fenol dan antioksidan pada produk, didapatkan hasil bahwa formula SSSB 3 mempunyai ranking nilai terbaik yang diikuti formula SSSB 2 dan formula SSSB 1. Berdasarkan hal tersebut didapatkan hasil bahwa formula SSB 3 menjadi terbaik.

Tabel 4. Perbedaan Kandungan Gizi Snack Bar Per Saji

\begin{tabular}{|c|c|c|c|c|c|c|}
\hline \multicolumn{7}{|c|}{ Formulasi SSSB 3} \\
\hline Zat Gizi & $\begin{array}{c}\text { Hasil Zat } \\
\text { Gizi } \\
(100 \text { gr })\end{array}$ & $\begin{array}{c}\text { Hasil Zat } \\
\text { Gizi } \\
(25 \text { gr })\end{array}$ & $\begin{array}{l}\text { USDA } \\
25048 \\
(25 \text { gr }) \\
\end{array}$ & $\begin{array}{c}\text { SNI } \\
01-4216-1996 \\
(25 \mathrm{gr})\end{array}$ & $\begin{array}{c}\text { Komersil }^{*} \\
(25 \text { gr) }\end{array}$ & $\begin{array}{c}\text { Keb. Pasien } \\
\text { Dislipid } \\
\text { (per saji) }\end{array}$ \\
\hline Energi (kkal) & 441 & 110 & 87 & 120 & 80 & 200 \\
\hline Karbohidrat (gr) & 60,32 & 15,08 & 15,25 & - & 14 & 40 \\
\hline Protein (gr) & 17,62 & 4,4 & 6,6 & 7,5 & 1 & 5 \\
\hline Lemak (gr) & 14,45 & 3,612 & 7,8 & $1,4-14$ & 2,5 & 5 \\
\hline Serat (gr) & 5,889 & 1,47 & 1,7 & - & 2 & - \\
\hline Air (gr) & 4,99 & 1,24 & 2,6 & - & - & - \\
\hline $\mathrm{Abu}(\mathrm{gr})$ & 2,626 & 0,656 & 0,4 & - & - & - \\
\hline Fenol (mg GAE) & 460,226 & 115 & - & - & - & - \\
\hline
\end{tabular}

Berdasarkan diet kebutuhan gizi pada pasien dislipidemia dengan standar kebutuhan energi 2000 $\mathrm{kkal} /$ hari, kebutuhan lemak $\leq 30 \%$ dari kebutuhan total. Lemak tak jenuh ganda dan tunggal disarankan sebesar $10-15 \%$ dari total kebutuhan. Kebutuhan lemak jenuh sebesar 7-10\% dari total kebutuhan. Dan kolesterol kurang dari 300mg. Kebutuhan karbohidrat sedang didasarkan $60 \%$ dan protein $10 \%$ dari kebutuhan energi untuk asupan makanan selingan. Kebutuhan karbohidrat pasien dislipidemia terutama monosakarida dibatasi dan dibutuhkan soluble dietary fiber 10-25 gram/hari untuk menjaga level trigliserida dan kolesterol. ${ }^{18}$

Kandungan snack bar terpilih per saji sebesar 25 gr memiliki kandungan energi yang hampir memenuhi standar SNI dan masih bisa diterima untuk kebutuhan pasien dislipidemia dikarenakan kebutuhan energi pasien dislipidemia bisa kurang dari ketentuan apabila makronutrien dan mikronutrien tercukupi, selain itu juga sesuai dengan tujuan diet yaitu kebutuhan energi bisa kurang atau sama dengan kecukupan energi. Selain itu, kandungan karbohidrat produk terpilih juga sudah sesuai dengan nilai USDA dan komersil akan tetapi dibandingkan untuk kebutuhan dislipidemia masih kurang. Kandungan lemak produk juga dapat dikatakan terpenuhi apabila disandingkan dengan SNI dan kebutuhan pasien, akan tetapi kurang dari standar USDA yang terlalu tinggi. Sedangkan kandungan protein sesuai dengan kebutuhan diet makanan selingan dislipidemia dan melebihi nilai komesil sedangkan untuk nilai USDA dan SNI dapat dikatakan terlalu tinggi apabila dibandingkan dengan produk terpilih. Kandungan serat juga sudah memenuhi USDA dan komersil. Kandungan air produk jauh lebih sedikit apabila dibandingkan dengan nilai USDA, hal ini dapat diartikan positif mengingat peran air dalam hal masa simpan. Sedangkan kandungan abu pada produk mempunyai nilai selisih yang tidak jauh berbeda dengan nilai dari USDA.

Kandungan total fenol pada formulasi terpilih sebesar 460,226 mg GAE/100 gram memiliki nilai yang hampir sama dengan kandungan total fenol pada beberapa varietas blackberries di Romania yaitu sekitar $442 \mathrm{mg}$ GAE/100 gram. ${ }^{19}$ Sedangkan apabila dibandingkan dengan kandungan total fenol pada teh hijau yang berasal dari Cikajang (P-IRT No. 810320501698) yaitu sebesar 334,68 mgGAE/100 gram, dapat dikatakan bahwa kandungan fenol produk terpilih untuk per 100 gram cukup baik. ${ }^{20}$ Apabila disandingkan dengan 
kandungan fenol pada teh yang telah diinfusi di Guangzhou dengan nilai sebesar 0,253-0,867 g GAE/L, maka untuk per sajian teh mengandung fenol sebesar 63,25-216,75 mgGAE/250 ml mempunyai nilai fenol yang tidak berbeda jauh dengan snack bar terpilih untuk per saji (25gram) sebesar 115 mgGAE. ${ }^{21}$

\section{PEMBAHASAN}

\section{Kandungan Zat Gizi}

Kandungan energi didapatkan berdasarkan perhitungan manual yang kemudian dilakukan uji statistik menunjukkan bahwa tidak terdapat perbedaan antara formulasi snack bar sesame seed dan tepung labu kuning terhadap energi. Kandungan energi terbaik terdapat pada formulasi ketiga yaitu sebesar 441,35 kkal. Nilai kandungan energi didapatkan dari penjumlahan konversi kandungan karbohidrat, lemak, protein, dan air. Perbedaan pemberian formulasi pada bahan dengan rasio yang tidak terlalu tinggi menjadi salah satu alasan kandungan energi tidak mempunyai perbedaan yang bermakna satu dan lainnya. Apabila formulasi terpilih yang mempunyai nilai energi 110,33 kkal dibandingkan dengan SNI 01-4216-1996 sebesar 120,93 kkal dan USDA 25048 (32 gram) sebesar 120 kkal maka dapat dikatakan hampir memenuhi ketentuan tersebut. Akan tetapi jika dibandingkan dengan komersil dengan slogan low calorie sebesar 80 kkal maka dapat dikatakan kurang memenuhi. Berdasarkan Departemen Kesehatan Pemerintah Australia standar kandungan energi untuk jenis makanan manis, snack, biskuit, dan bars per sajian sebesar143,43 kkal atau kurang dari nilai tersebut. ${ }^{22}$ Kebutuhan energi pada makanan selingan umumnya merupakan $10 \%$ dari kebutuhan energi secara keseluruhan untuk 2000kkal/hari sebesar $200 \mathrm{kkal}$ atau kurang dari nilai tersebut sesuai dengan kebutuhan. Akan tetapi kebutuhan energi produk yang tidak sesuai dengan kebutuhan diet ini seharusnya tidak menjadi masalah mengingat kebutuhan energi pada pasien dislipidemia bisa kurang dari yang telah ditentukan. Formulasi terpilih bisa dikatakan memenuhi kriteria tersebut.

Sedangkan kandungan karbohidrat didapatkan dengan perhitungan by difference, berdasarkan tabel 3 dapat diketahui bahwa tidak terdapat perbedaan formulasi snack bar terhadap kandungan karbohidrat. Nilai karbohidrat didapatkan berdasar pengurangan terhadap kandungan proksimat lainnya. Perbedaan rasio bahan tiap formulasi yang sedikit memberikan nilai makronutrien yang tidak jauh berbeda pada tiap jenis formulasi. Produk formulasi SSSB 1 mempunyai nilai karbohidrat terbaik yaitu sebesar 62,56 gr/100gram. Apabila melihat formulasi terbaik dibandingkan dengan kandungan karbohidrat snack bar komersil maka didapatkan nilai yang hampir sama yaitu masing-masing sebesar 15,08 gram/25gram dan 14 gram, sedangkan USDA 25048 mempunyai nilai karbohidrat 21,35 gram dan standar kebutuhan diet sebesar 40 gram. Selain karbohidrat berperan dalam menyumbang kebutuhan energi, karbohidrat dalam bentuk straches dalam biji-bijian mempunyai peran dalam mengentalkan dan menstabilkan produk. Sedangkan dietary fiber yang termasuk sumber karbohidrat juga mempunyai peran dalam meningkatkan tekstur, agen pengental, mengatur kelembaban dalam penggantian lemak, menambah warna, dan memberikan volume pada produk. ${ }^{23}$

Kandungan protein tertinggi terdapat pada formulasi SSSB 1 yaitu sebesar 18,94 gr/100 gram. Sedangkan terendah terdapat pada formulasi SSSB 2 sebesar 16,95 gr/100 gram. Berdasarkan uji statistik didapatkan hasil bahwa tidak ada beda antara formulasi snack bar sesame seed dengan kandungan protein. Sesame seed menjadi bahan penyumbang terbesar kandungan protein. Kandungan protein pada sesame seed sendiri diperkirakan 20-27\%, hal tersebut menjadikan sesame seed sebagai sumber pangan pontesial protein. Selain itu juga sesame seed mempunyai kandungan asam amino essential yang adekuat seperti methionin, cysteine, dan trytophan. Studi menyebutkan kandungan asam amino protein isolat sesame seed yang tertinggi adalah glutamic acid $(16,54 \mathrm{~g} / 100 \mathrm{~g})$ dan diikuti ascpartic acid $(9,88 \mathrm{~g} / 100 \mathrm{~g})$. Selain itu, essential amino acid (EAA) yang tertinggi adalah leucine $(7,57 \mathrm{~g} / 100 \mathrm{~g})$, isoleucine $(4,85 \mathrm{~g} / 100 \mathrm{~g})$, methionine $(1,87 \mathrm{~g} / 100 \mathrm{~g})$, arginine $(7,45 \mathrm{~g} / 100 \mathrm{~g})$, serine $(6,62$ $\mathrm{g} / 100 \mathrm{~g})$, valine $(5,44 \mathrm{~g} / 100 \mathrm{~g})$, dan histidine $(2,25 \mathrm{~g} / 100 \mathrm{~g}) .^{24}$ Bahan komponen utama lainnya yaitu tepung labu kuning sendiri mempunyai kandungan protein 7,81\% tiap 100 gram.

Berdasarkan uji statistik yang telah dilakukan didapatkan hasil bahwa tidak ada beda antara forumlasi snack bar sesame seed dan labu kuning terhadap kandungan lemak. Dari penjabaran data yang terdapat pada tabel menunjukkan bahwa kandungan tertinggi lemak terdapat pada produk dengan formulasi SSSB 3 yaitu sebesar 14,45. ALA (Alpha linolenic acid) yang merupakan asam lemak omega-3 menjadi komponen utama pembentuk polyunsaturated fatty acid pada sesame seed. ALA tidak dapat disintesis oleh tubuh sehingga harus dipenuhi dengan asupan harian terutama dari sesame seed. ${ }^{25}$ Lebih dari $80 \%$ sumber fatty acid pada sesame berupa oleic dan linoleic acid. Linoleic acid menyumbang 42,9-54\% total fatty acid dilanjutkan oleic acid 31,6-42\%, palmitic 7,2-9,7\%, dan staeric acid 3,8-5,6\%. ${ }^{25}$ Kandungan lemak pada tepung labu 
kuning sendiri tergolong sedikit yaitu berkisar 3,6\% per seratus gram. Penambahan bahan makanan lain yang mengandung lemak dalam proses pembuatan snack bar juga mampu meningkatkan kandungan lemak. Penyajian margarin per $14 \mathrm{~g}$ memberikan kontribusi lemak sebesar 7,1 gram dan 0,2 gram trans fatty acid dan memberikan kebutuhan harian lemak sebesar $22 \%$ omega-3 $\alpha$-linolenic acid dan $15 \%$ omega-6 linoleic acid untuk kebutuhan orang dewasa. ${ }^{26}$ Apabila kandungan lemak snack bar terpilih dibandingkan sebesar 3,615 gram dengan kebutuhan diet dislipidemia sebesar 5 gram maka dapat dikatakan belum bisa memenuhi. Akan tetapi apabila dilihat dari kebutuhan lemak untuk pasien dislipidemia bisa kurang dari yang direkomendasikan, hal ini dikaitkan juga dengan pembatasan kebutuhan lemak pada pasien dislipidemia.

Hasil uji statistik menyatakan terdapat perbedaan formulasi snack bar sesame seed dan tepung labu kuning terhadap serat $(p=0,011)$. Sesame seed sendiri sebenarnya buka sumber pati yang bagus akan tetapi mengandung sekitar seperempat serat larut dari total serat yang ada dalam sesame seed. Bagian utama serat larut tersebut adalah mucilaginous gum dengan komposisi 8-11 gram per 100 gram. ${ }^{25}$ Sedangkan tepung labu kuning mengandung setidaknya $40 \%$ selulosa, $4,3 \%$ hemiselulosa, dan 4,3\% lignin. ${ }^{27}$ Dchiro-inositol yang diidentifikasi dalam labu kuning dianggap sebagai mediator aksi insulin dengan beberapa mekanisme. Komponen lain yang berperan dalam hal ini adalah fitokimia fenolik labu yang mempunyai efek anti-diabetes dengan menghambat b-glukosidase dan a-amilase. Telah diketahui juga bahwa beberapa substansi pada buah labu isolasi ikatan protein-polisakarida mampu memperbaiki toleransi terhadap glukosa pada hewan diabetes yang diinduksi alloxan. ${ }^{28}$

Serat mempunyai sifat sebagai komponen yang mampu mengikat beberapa substansi seperti kolesterol dan asam lambung, selain itu serat mempunyai peran dalam pencegahan diabetes, obesitas, aterosklerosis, penyakit jantung, kanker usus besar, dan kanker kolorektal. Serat juga mampu mempengaruhi konsentrasi serum lipid, menurunkan tekanan darah, mempengaruhi kadar gula darah, dan membantu penurunan berat badan. Makanan yang disiapkan dengan tambahan tepung labu kuning mempunyai mamnfaat terutama dalam tambahan kandungan vitamin, mineral, dan serat. Sumber karotenoid, provitamin A, dan asam askorbat berperan penting sebagai antioksidan yang mempunyai berbagai macam manfaat pada kesehatan. ${ }^{27}$
Hasil uji statistik juga menyebutkan terdapat perbedaan pada formulasi snack bar sesame seed dan labu kuning dengan kadar abu $(p=0,000)$. Kadar abu sendiri menggambarkan campuran komponen anorganik atau mineral yang terdapat pada bahan makanan. Abu bisa menggambarkan kandungan mineral yang terdapat dalam bahan, selain itu juga mampu memperlihatkan kemurnian dan kebersihan bahan. ${ }^{29}$ Formulasi SSSB 2 mempunyai kadar abu tertinggi yaitu 7,15 sejalan dengan kandungan air pada produk. Sesame seed sendiri mempunyai berbagai macam kandungan mineral meliputi $\mathrm{Fe}$ $(19,2 \mathrm{mg} / 100 \mathrm{~g})$, kalsium $(960 \mathrm{mg} / 100 \mathrm{~g})$, phospor $(659 \mathrm{mg} / 100 \mathrm{~g})$, zinc $(7,29 \mathrm{mg} / 100 \mathrm{~g})$, copper $(4,214$ $\mathrm{mg} / 100 \mathrm{~g})$, selenium $(35,5 \mu \mathrm{g} / 100 \mathrm{~g})$, magnesium $(362 \mathrm{mg} / 100 \mathrm{~g})$, dan mangan $(2,54 \mathrm{mg} / 100 \mathrm{~g}) .{ }^{10}$ Sedangkan tepung labu kuning sendiri mempunyai kandungan mineral berupa $\mathrm{Fe}(10,6 \mathrm{mg} / 100 \mathrm{~g})$, magnesium $(159 \mathrm{mg} / 100 \mathrm{~g})$, phospor $(584 \mathrm{mg} / 100 \mathrm{~g})$, copper $(1,3 \mathrm{mg} / 100 \mathrm{~g})$, dan selenium $(4 \mathrm{mcg} / 100 \mathrm{~g})$.

Formulasi snack bar sesame seed dan tepung labu kuning mempunyai perbedaan terhadap kandung air, hal ini sesuai dengan uji statistik yang telah dilakukan $(p=0,009)$. Air menjadi komponen penting dalam pangan, air bebas yang terdapat pada ruang antar sel membantu terjadinya kerusakan bahan pangan baik secara proses mikrobiologi, kimiawi, enzimatik, dan serangga. Sedangkan air dalam bentuk terikat dan terikat kuat tidak membantu terjadinya proses kerusakan pangan. ${ }^{29}$ Formulasi SSSB 2 mempunyai nilai rerata kandungan air tertinggi yaitu 7,41. Labu kuning sendiri memiliki kandungan air yang tinggi yaitu $96 \%$, pengeringan bahan makanan akan mengurangi kandungan air untuk mencegah terjadinya kerusakan pangan.

\section{Kadar Aktivitas Antioksidan}

Berdasarkan pengujian aktivitas antioksidan dengan menggunakan metode DPPH yang didapatkan berupa \% inhibisi menunjukkan bahwa terdapat perbedaan formulasi snack bar sesame seed dan tepung labu kuning terhadap aktivitas antioksidan $(p=0,025)$. Metode DPPH sendiri didasarkan pada pengurangan DPPH menjadi radikal bebas yang stabil. DPPH dengan elektron ganjil sendiri mampu memberikan penyerapan maksimum pada nilai $517 \mathrm{~nm}$ atau pada warna ungu. Antioksidan bereaksi dengan DPPH dan menjadi berpasangan dengan memberikan donor hidrogen yang kemudian direduksi menjadi DPPH. Hal tersebut menyebabkan penurunan absorbansi DPPH, radikal dalam bentuk DPPH menghasilkan dekoloriasasi warna kuning sesuai dengan jumlah elektron yang ditangkap. ${ }^{30}$

Dilihat dari tabel aktivitas antioksidan tertinggi terdapat pada formulasi SSSB 3 dengan 
kadar sesame seed 85\% dan tepung labu kuning 5\% yaitu dengan rerata 93,43\%. Sedangkan aktivitas antioksidan terendah terdapat pada formulasi SSSB 1 dengan rerata 92,207\%. Kombinasi yang menguntungkan antara kedua bahan utama yaitu sesame seed dan tepung labu kuning menjadi salah satu faktor aktivitas antioksidan terhadap produk snack bar. Unsur yang terdapat pada sesame seed seperti sesamolin dan sesamol mempunyai peran sebagai antioksidan yang larut dalam lemak. ${ }^{25}$ Selain itu lignan glycoside yang terdapat pada sesame seed mempunyai peran dalam peningkatan antioksidan dan memberikan stabilitas vitamin E secara in vitro dan invivo. Dilaporkan bahwa kandungan sesamin dan sesamolin pada sesame seed sebesar 300$400 \mathrm{mg} / 100$ gr. 25 Sesame coat sendiri juga mempunyai aktivitas antioksidan yang signifikan terutama perannya dalam sistem lipid peroksidase in vitro. Tetranortriterpenoid dan komponen fenolik menjadi senyawa penting pada aktivitas antioksidan pada sesame seed.

Studi melaporkan penambahan tepung labu kuning meningkatkan kandungan $\beta$-karoten pada produk mie. Labu kuning sendiri menjadi salah satu bahan makanan dengan sumber karotenoid dan ascorbic acid yang baik, dimana kedua senyawa tersebut mempunyai peran sebagai provitamin A atau sebagai antioksidan. Selain itu juga ditemukan $\alpha, \beta$ karoten, lutein, cryptoxanthin, dan zeaxanthin yang mempunyai peran sebagai flavonoid pada labu kuning. ${ }^{31}$ Ascorbic acid juga mempunyai peran melindungi membran dari peroksidasi dengan meningkatkan aktivitas tokoferol. Secara in vitro studi menunjukkan bahwa ascorbic acid mereduksi tocopheroxyl radical dan mengembalikan aktivitas radical-scavenging tokoferol. $^{32}$ Proses pemanggangan sesame seed juga mempunyai efek dalam peningkatan aktivitas antioksidan, hal ini dikarenakan adanya pembentukan produk pada reaksi Maillard. Efek pemanggangan terhadap aktivitas antioksidan tergantung pada keseimbangan degradasi termal secara alami pada senyawa antioksidan dan pembentukan produk baru yang memiliki aktivitas antioksidan. Banyak peneliti yang menunjukkan adanya korelasi positif antara total fenol dan aktivitas antioksidan. Studi juga menyebutkan adanya peningkatan komponen senyawa fenolik pada proses pemanggangan 90 menit pertama dengan suhu $90-100^{\circ} \mathrm{C} .^{33}$

Antioksidan berperan dalam proses penghambat oksidasi dan mempunyai peran fisiologis dalam tubuh. Konstituen antioksidan bertindak sebagai radikal scavenging dan membantu konversi radikal menjadi spesies yang kurang reaktif. Sistem antioksidan non enzimatik meliputi komponen fitokimia seperti fenol, flavonoid, dan karetoneid mempunyai peran sebagai radikal scavenging pada komponen radikal seperti $\mathrm{O}^{2}, \mathrm{OH}$, dan lipid peroxyl radikal LOO yang terdapat dalam plasma. $^{34}$

\section{Kadar Total Fenol}

Berdasarkan uji statistik yang telah dilakukan terdapat perbedaan perbedaan formulasi snack bar sesame seed dan tepung labu kuning terhadap kadar total fenol. Formulasi SSSB 3 memiliki nilai rerata kadar fenol terbaik yaitu sebesar 460,266 mg GAE. Nilai total fenol tertinggi pada formulasi ini sejalan dengan nilai aktivitas antioksidan yang terdapat pada tabel sebelumnya. Berdasarkan data, peningkatan penambahan tepung labu kuning pada produk sejalan dengan peningkatan kandungan total fenol. Penelitian yang dilakukan oleh Phanlert et al dengan penambahan tepung labu kuning yang berbeda terhadap snack ekstrudat menunjukkan bahwa semakin tinggi kandungan total fenol sesuai dengan peningkatan penambahan tepung labu kuning. ${ }^{35}$ Komponen fenolik pada struktur molekular membantu meningkatkan kapasitas aktivitas antioksidan. Beberapa komponen fenolik yang terdapat pada labu kuning meliputi tannin dan flavonoid menjadi kontributor terbesar dalam kapasitas antioksidan. Kandungan total fenol pada buah labu kuning berkisar 5,19 mg GAE/g. ${ }^{36}$

Beberapa flavonoid yang terdapat pada sesame seed meliputi epicatechin, procyanidin, guercin, dan catechin. Procyanidin sendiri mampu mengurangi peroksidasi lipid dari kolestrol lipoprotein dan mampu meningkatkan kemampuan pembersihan radikal bebas. Procyanidin juga mempunyai pengaruh pada jaringan vascular dan mempunyai partisipasi dalam pertahanan elastin dan kolagen dengan secara kuar mengurangi enzim yang berkaitan dengan denaturasi elastin, kolagen, dan asam hialuronat. Lignan yang merupakan salah satu bentuk polifenol terdapat pada sesame seed terutama sesamin mampu mengikat dan mengaktifkan reseptor dalam tubuh yaitu Peroxisome Proliferator Activator Receptor Alpha (PPARalpha) yang sangat tinggi diekspresikan dalam otot, hati, ginjal, dan jantung. Selain itu, reseptor tersebut terlibat dalam pengaturan pengaturan metabolisme lipid, khususnya transkripsi gen yang terlibat dalam oksidasi lemak dan lipogenesis. Aktifasi PPARalpha menigkatkan ekspresi gen enzim oksidasi asam lemak dan mengurangi ekspresi gen enzim lipogenik. Dapat disimpulkan bahwa sesame seed meningkatkan proses pembakaran lemak dan mengurangi penyimpanan lemak dalam tubuh. Percobaan pada tikus menemukan bahwa sesnyawa tersebut mampu mencegah peningkatan kadar serum triasilgliserol. ${ }^{37}$ 
Ada beberapa alasan polifenol berpengaruh terhadap pengurangan beberapa penyakit kronis maupun degeneratif. Hal tersebut meliputi dalam menghambat modulasi/regulasi jalur persinyalan sel pengurangan agregasi trombosit, mempengaruhi efek pada sintesis kolesterol, metabolism hormon, dan efek sebagai antioksidan. Komponen fenolik juga ditemukan menghambat enzim inflamasi seperti PLA2, COX-1/2, dan LOX. Selain itu mampu mengurangi proliferasi sel, angiogenesis, imobilisasi leukosit, dan mengurangi aktivitas enzim 5lipoksigenase. ${ }^{38}$

\section{Mutu Organoleptik}

Uji hedonik sebagai penilaian mutu organik sangat penting pada industri pengolahan makanan, hal ini mencakup teknik pengukuran dari reaksi manusia terhadap bahan makanan yang akhirnya mampu meyakinkan persepsi konsumen. Evaluasi sensorik sendiri merupakan metode ilmiah yang mempunyai peran dalam membangkitkan, mengukur, menganalisa, dan menginterpertasikan respon terhadap produk sesuai dengan yang dirasakan indera manusia meliputi pendengaran, menyentuh, merasakan, penglihatan, dan merasakan. ${ }^{39}$

Berdasarkan hasil uji statistik menunjukkan tidak adanya perbedaan kualitas warna terhadap snack bar. Apabila dilihat secara fisik dari segi formulasi produk snack bar, perbedaan pemberian sesame seed dan tepung labu kuning menghasilkan warna yang berbeda tiap jenis formulasi meskipun perbedaan warna tidak mencolok. Semakin sedikit pemberian tepung labu kuning pada produk menghasilkan warna yang lebih cerah dibandingkan dengan pemberian tepung labu kuning yang besar. Akan tetapi warna yang dihasilkan masih terlihat baik dan menarik bagi panelis dan tidak terdapat perbedaan yang bermakna. Apabila dilihat dari ranking nilai rata-rata, maka produk snack bar formulasi SSSB 3 mempunyai warna yang paling disukai panelis. Penambahan tepung labu kuning terhadap produk memberikan tambahan warna kuning dan sedikit merah. Hal tersebut dikarenakan banyaknya kandungan $\beta$ karoten yang terdapat pada labu kuning. ${ }^{39}$ Karotenoid termasuk dalam kategori tetraterpenoids memberikan pigmen warna alami pada produk berupa yellow-orange-red yang biasanya banyak ditemukan dibanyak buahbuahan. ${ }^{40}$ Selain itu, reaksi Maillard atau nonenzimatik browning mempunyai peran terhadap perubahan warna pada produk. Hal tersebut terjadi ketika makanan diproses atau dimasak dalam suhu tinggi yang kemudian terjadi reaksi kimia antara asam amino dan reduksi kandungan gula. Reaksi tersebut memberikan pengaruh terhadap rasa dan memberikan warna coklat. ${ }^{41}$ Produk formula ketiga mempunyai warna orange-coklat yang tidak terlalu gelap. Warna produk termasuk dalam penampilan mempunyai peran penting dalam penilaian produk mengingat penampilan merupakan karakteristik pertama yang dirasakan indera manusia dalam identifikasi dan pemilihan akhir makanan. Persepsi mengenai visual makanan meliputi warna, kusam, kilap, dan transparansi menunjukkan memiliki dampak pada stimulasi nafsu makan atau menghasilkan kesenangan terhadap produk.

Berdasarkan tingkat kesukaan terhadap aroma produk, hasil uji statistik menunjukkan bahwa tidak adanya perbedaan aroma pada produk snack bar sesame seed dan tepung labu kuning. Produk dengan formulasi SSSB 1 dan SSSB 2 mempunyai nilai tertinggi yang sama. Aroma yang terdapat pada produk disebabkan oleh beberapa hal meliputi penambahan bahann makanan vanilla essence, cinnamon powder, aroma caramel dari sirup agave, dan aroma yang berasal dari tepung labu kuning itu sendiri. Selain itu reaksi Maillard juga memberikan pengaruh terhadap perubahan aroma pada produk. Aroma sendiri menjadi penilaian fisik yang dirasakan oleh reseptor bau pada jaringan penciuman di rongga hidung. Aroma sendiri merupakan senyawa volatil yang mudah menguap dan mampu dilepaskan selama proses pengunyahan. Aroma juga mampu membuat produk makanan menjadi lezat. ${ }^{42}$

Tabel 2 menunjukkan bahwa produk dengan formulasi SSSB 3 mempunyai tekstur yang paling banyak disukai. Berdasarkan uji Kruskal Wallis yang telah dilakukan tidak terdapat perbedaan pada aspek tekstur terhadap snack bar sesame seed dan tepung labu kuning. Produk mempunyai tekstur yang crunchy dikarenakan bahan sesame seed itu sendiri. Tekstur menjadi salah satu prasyarat dalam penerimaan produk makanan yang meliputi konsistensi, ketebalan, kerapuhan, kekenyalan, dan bentuk atau ukuran partikel dalam produk makanan. Pada studi penelitian Kulkarni dan Joshi penggantian tepung terigu dengan tepung labu kuning pada produk biskuit menghasilkan perubahan signifikan dalam kualitas tekstural biskuit. Peningkatan penggantian tepung labu kuning terhadap produk dari 0\%-10\% membutuhkan peningkatan jumlah kekuatan yang digunakan untuk penghancuran. Selain itu, peningkatan 5\%, 7,5\%, dan $10 \%$ tepung labu kuning meningkatkan level kekerasan masing-masing 2853, 3009, dan 3263g. Hal ini disebabkan karena kapasitas penyerapan air pada tepung gandum lebih tinggi dibandingkan dengan tepung labu kuning. ${ }^{43}$

Rasa membantu dalam identifikasi, penerimaan, dan apresiasi produk makanan. Berdasarkan uji statistik Kruskal Wallis tidak 
ditemukan perbedaan pada aspek rasa terhadap snack bar sesame seed dan tepung labu kuning. Akan tetapi, produk snack bar yang paling disukai dalam hal rasa adalah produk dengan formulasi SSSB 1. Panelis berpendapat bahwa rasa yang dihasilkan yaitu gurih dan manis, serta kombinasi keduanya yang menjadikan produk mempunyai rasa unik. Bahan baku utama produk yaitu tepung labu kuning sendiri umumnya memberikan rasa yang diinginkan yaitu manis. ${ }^{39}$ Selain itu sesame seed sendiri mempunyai tekstur yang crunchy dan rasa seperti kacang juga memberikan efek rasa gurih. Sedangkan bahan tambahan pangan lain seperti sirup agave selain mempunyai peran sebagai penyatu bahan juga memberikan rasa manis pada produk.

\section{SIMPULAN}

Tidak terdapat perbedaan antara formulasi snack bar dan tepung labu kuning terhadap tingkat penerimaan, kandungan energi, karbohidrat, protein, dan lemak. Kemudian berdasarkan kandungan serat air, abu, aktivitas antioksidan, dan total fenol memiliki perbedaan dengan formulasi snack bar sesame seed dan labu kuning. Formulasi terpilih merupakan formulasi snack bar dengan rasio sesame seed $85 \%$ dan tepung labu kuning $15 \%$.

1 Modifikasi produk untuk penelitian selanjutnya mempertimbangkan formulasi untuk memenuhi kandungan gizi yang kurang berdasarkan beberapa standar yang ada. Selain itu diperlukan penelitian lebih lanjut mengenai pengaruh snack bar sesame seed dan tepung labu kuning terhadap marker oksidatif stress, profil lipid, dan marker penyakit kardiovaskular lainnya untuk melihat efektifitas produk. Diperlukan uji spesifik jenis kandungan polifenol yang berperan besar efeknya terhadap kesehatan.

\section{DAFTAR PUSTAKA}

1. Ekpenyong C.E, Udokang N.E, Akpan E.E, Samson . Double Burden, Non-Communicable Diseases And Risk Factors Evaluation In SubSaharan Africa: The Nigerian Experience. European Journal of Sustainable Development. $2012(1,2): 249-270$.

2. Adil S, Talgat N, Zhaxbay Z, Anne P, Jaroslav A. Hubacek, Martin B. Prevalence, awareness, treatment and control of dyslipidemia in older persons in urban and rural population in the Astana region, Kazakhstan. BMC Public Health. 2017; 651(17) :1-9.

3. MSD Manual Professional Edition. Dyslipidemia (Hyperlipidemia). Available:www.msdmanuals.com/professional/ endocrine-and-metabolic-disorders/lipiddisorders/dyslipidemia
4. World Health Organization. Global status report on Non-Communicable diseases2010.Available:www.who.int/nmh/publ ications/ncd_report_full_en.pdf

5. Mohammad RM, Esfandiar H, Soleiman K, Mahmoud IRK. Effect of hydroalcoholic Allium ampeloprasum extract on oxidative stress, diabetes mellitus and dyslipidemia in alloxan-induced diabetic rats. Biomedicine \& Pharmacotherapy, Elseveir. 2017;86 :363-367

6. Baradaran A., Kopaei RM., Oxidative stress and hypertension: possibility of hypertension therapy with antioxidants, J. Res. Med. Sci. 2014; 19 (4)

7. Rui LY, Yong HS, Gang H, Wu L, Guo WL. Increasing Oxidative Stress with Progressive Hyperlipidemia in Human: Relation between Malondialdehyde and Atherogenic Index. J. Clin. Biochem. Nutr. 2008;43:154-158

8. Madiseh RM., Arjenaki GM., Bahmani M., Mardani G., Farzan M., Kopaei RM., Evaluation of minerals, phenolics and antiradical activity of three species of Iranian berberis fruit, Der Pharma. Chem. 2016;8 (2) :191-197.

9. Manisha, Whidul H, Richa R, Depali J. Oxidative Stress And Antioxidants: An Overview. International Journal of Advanced research and Review. 2017;2(9) :110-119

10. Nagendra Prasad MN, Prasad S. Deepika KR, Neha Vijay, Ruchiks Kothari, Nanjunda Swamy S. A Review on Nutritional and Nutraceutical Properties of Sesame. J Nutr Food Sci. 2012; 2(2) : $1-6$

11. Moazzami, A. A, Andersson R.E, Eldin Kamal. HPLC Analysis Of Sesaminol Glucoside In Sesame Seeds. J. Agric Food Chem. 2006; 54 :633-638

12. Barbosa CVdS, Silva AS, Oliveira de, Massa NML, de YRF Soursa, de Costa WKA, Silva AC, Delatorre P, Carvalho R, Braga VdA, Magnani M. Effects of Sesame (Sesamum indicum L) Supplementation on Creatine Kinase, Lactate Dehydrogenase, Oxidative Stress Markers, and Aerobic Capacity in SemiProfessional Soccer Players. Front Physiol.2017;8(196): 1-7

13. Rizvi S, Raza TS, Mahdi F. The Role of Vitamin E in Human Health and Some Diseases. Sultan Qaboos University Medical Journal.2014;14(2): 157-165.

14. Ide T, Azechi A, Kitade S, Kunimatsu Y, Suzuki N. Comparative Effects of Sesame Seeds Differing in Lignan Contents and Composition on Fatty Acid Oxidation in Rat 
Liver. Journal of

Science. 2015;64(2): 211-222

15. Chen RP, Chien LK, Su CT, Chang JC, Liu LT. Dietary sesame reduces serum cholesterol and enhances antioxidant capacity in hypercholesterolemia. Nutrition

Research. 2005;25(0): 559-567

16. Lima PPG, Vianello F, Corrêa RC, Campos SDARenê, Borguini GM. Polyphenols in Fruits and Vegetables and Its Effect on Human Health. Food and Nutrition Sciences. 2014;5(0): 1065-1082.

17. Srebernich MS, Çalves GSMG, Ormenese CSCSR, Ruffi GRC. Physico-chemical, sensory and nutritional characteristics of cereal bars with addition of acacia gum, inulin and sorbitol. Food Science and Technology.2016;36(3): 555-562

18. Chee JK. 2015 Korean Guidelines for the Management of Dyslipidemia: Executive Summary (English Translation). Korean Circulation Journal. 2016;46(3): 275-306.

19. Zoriţa d, Florica r, Dumitriţa r, Loredana 1, Oana p. Phenolic Content and Their Antioxidant Activity in Various Berries Cultivated in Romania.Bulletin UASVM Food Science and Technology. 2015;72(1): 1-5.

20. M kusmiyati, Y sudaryat, Ia lutfiah, A rustamsyah, D rohdiana. Aktivitas antioksidan, kadar fenol total, dan flavonoid total dalam teh hijau (Camellia sinensis (L) O Kuntze) asal tiga perkebunan Jawa Barat. Jurnal Penelitian Teh dan Kina. 2015;18(2): 101-106.

21. Li Fu, Bo TX, Ren YG, Zhang Y, XiangRX. Total Phenolic Contents and Antioxidant Capacities of Herbal and Tea Infusions. Int $\mathrm{J}$ Mol Sci.2011;12(0): 2112-2124.

22. Healthgovau. Healthgovau. [Online]. Available from:

https://www1.health.gov.au/internet/publication s/publishing.nsf/Content/canteen-mgr-

tr2 nutrient-criteria-tables [Accessed 21 July 2019].

23. Filiz Y. The Application of Dietary Fibre in Food Industry: Structural Features, Effects on Health and Definition, Obtaining and Analysis of Dietary Fibre: A Review . Journal of food and nutrition research. 2013;1(3): 13-23

24. Temitope OF, Saka OG, Taiwo OM. Characterization of protein isolate from Sesamum indicum seed: In vitro protein digestibility, amino acid profile, and some functional properties. Food Sci Nutr. 2018;6(0): 1715-1723

25. Asghar A, Majeed NM, Akhtar NM. A review on the utilization of sesame as functional

\section{food. American Journal Of Food And} Nutrition. 2014;4(1): 21-34.

26. Marcella G, Douglas AB, Peter $1 \mathrm{Z}$, Wendy AB, Anne JW. Fat composition of vegetable oil spreads and margarines in the USA in 2013: a national marketplace analysis. International Journal Of Food Sciences And Nutrition. 2016;67(4): 372-382.

27. Aukkanit N, Sirichokworrakit S. Effect Of Dried Pumpkin Powder On Physical, Chemical, And Sensory Properties Of Noodle. International Journal of Advances in Science Engineering and Technology. 2017;5(1): 14-18

28. Judita $\breve{C}$, Jurgita K, Honorata DČ, Elvyra J, Edita J . Pumpkin Fruit Flour as a Source for Food Enrichment in Dietary Fiber. Not Bot Horti Agrobo,. 2014;42(1): 19-23.

29. Young w park, phd. Moisture And Ash Contents Of Foods. In: Leo ml nollet (ed.) Handbook of Food Analysis. New York: CRC Press; 1996. p. 1-42

30. Tailor CS, Goyal A. Antioxidant Activity by DPPH Radical Scavenging Method of Ageratum conyzoides Linn Leaves. American Journal of Ethnomedicine. 2014;1(4): 244-249.

31. Nguyen VT, Nguyen TTT. Production of highquality flour and the made biscuits from Pumpkin. International Journal of Food Science and Nutrition. 2018;3(5): 157-166.

32. Helmut S, Wilhelm S. Vitamins E and C, BetaCarotene, and Other Carotenoids as Antioxidants. American Journal of Clinical Nutrition. 1996;62(6): 1315S-1321S.

33. Rizki H, Kzaiber F, Elharfi M, Ennahli S, Hanine H. Effects of roasting temperature and time on the physicochemical properties of sesame (Sesamum indicum L) seeds. International Journal of Innovation and Applied Studies. 2015;11(1): 148-155.

34. Ssaeleaw M, Schleining G . The 12th International Congress on Engineering and Food (ICEF) . [Online]. Available from: http://www.icef11.org/ [Accessed 7 February 2019].

35. Phanlertpromsakha NSN, Kamolwanjangchud, Anuvatjangchud,

Chulaluckcharunuch. Optimization of pumpkin and feed moisture content to produce healthy pumpkin-germinated brown rice extruded snacks. Agriculture and Natural Resources. 2018;52(6): 550-556.

36. Mala Sathiya K, Anjali E. Nutritional Composition And Antioxidant Activity Of Pumpkin Wastes. International Journal Of 
Pharmaceutical, Chemical And Biological Sciences . 2016;6 (3): 336-344 .

37. Anilakumar RK, Pal A, Khanum F, Bawa SA. Nutritional, Medicinal and Industrial Uses of Sesame (Sesamum indicum L) Seeds - An Overview . Agriculturae Conspectus Scientifi cus. 2010;75(4): 159-168.

38. Rasouli H, Farzaei HM, Khodarahmi R. Polyphenols and their benefits: A review. International Journal of Food Properties. 2017;20(2): S1700-S1741.

39. See E, Wan NW, Noor AA. Physico-Chemical and Sensory Evaluation of Breads Supplemented with Pumpkin Flour. ASEAN Food Journal . 2007;14(2): 123-130.
40. Alan M. Carotenoids and other pigments as natural colorants*. Pure Appl Chem. 2006.;78(8): 1477-1491.

41. Nahid T, Niaz M. Food Processing and Maillard Reaction Products: Effect on Human Health and Nutrition. International Journal of Food Science. 2015;0(0): 1-6.

42. Mian KS. Sensory Evaluation and Consumer Acceptability . In: Tahir zahoor, Masood sadiq butt (eds.) Handbook of Food Science and Technology, . Pakistan: Niversity of Agriculture Faisalabad; 2017. p. 362-386.

43. Kulkarni as, Joshi dc. Effect of replacement of wheat flour with pumpkin powder on textural and sensory qualities of biscuit. International Food Research Journal. 2013;20(2): 587-591. 